\title{
Stages of Development of the Russian-Japanese Trade and Economic Relations
}

\author{
Natalia Victorovna Kuznetsova ${ }^{1}$ \& Aleksandra Olegovna Lapteva ${ }^{1}$ \\ 1 Far Eastern Federal University, Russia \\ Correspondence: Natalia Victorovna Kuznetsova, Federal University, , Primorskii Region, Russkii Island, V. \\ Ayaks, 10, Building 22 (G), 690950, Russia.
}

Received: May 26, 2014 Accepted: June 18, 2014 Online Published: July 29, 2014

doi:10.5539/ass.v10n15p236 URL: http://dx.doi.org/10.5539/ass.v10n15p236

\begin{abstract}
Main purpose of the article is to classify the stages of development of Russian-Japanese economic and trade relation. Special attention is given to revealing of the features, tendencies, and characteristics of the present stage of development of the Russian-Japanese trade and economic relations. Interaction of two countries in 2000-2013 has provided an active growth of turnover. The basic priority of interaction noted in such spheres of trade as mechanical engineering, power, woods, and chemical industry. It is obvious that trade of Russia with Japan still has a character of exchange of the Russian fuel, raw materials, and seafood on the Japanese finished industrial products. The basic priorities of cooperation in such sectors as trade, mechanical engineering, energy, wood, and chemical industry are defined. Right during the newest period of 2000-2013, integration of the Russian-Japanese business on territory of the Russian Federation has got the rebirth, having embodied in numerous spheres of the Russian economy. The energy sphere is still a leading sphere of trade and economic relations of Russia and Japan.
\end{abstract}

Keywords: trade and economic relations, stages of development, turnover, trade structure, intergovernmental agreements

\section{Introduction}

Mutual interest of Russia and Japan in structuring, expansion, and deepening of all-round relations is an objective reality of today.

The history of the Russian-Japanese trade and economic relations has a long way. Many scientists had an interest to this subject. They brought up questions on the Russian-Japanese trade and economic relations of the Russian Far East and Japan, as well as whence these relations began. The Japanese researcher M. Seigo (元木省吾) in his book "Hoppo torai" tells about I.A.Goshkevich's contribution to the formation of the Russian-Japanese relationships (Seigo, 1961). Abe Masami (安部正見) in the book "Goshkevich, Russian consul in Hakodate" notes I. A. Goshkevich's contribution to the formation of the Russian-Japanese relations and openly expresses his admiration of this person, naming him as "the White-haired consul" (Masami, 1920) who observed local customs, did not touch national dignity of Japanese people, and rendered them the feasible help. Famous American historian G. A. Lensen in his work «the Remains of Russian culture in Northern Japan» describes Russian expeditions in the Far East in XVIII-XIX centuries, as well as the Russian-Japanese negotiations on a territorial dispute (Lensen, 1954).

A starting point of the Russian-Japanese trade and economic relations setting is considered to be February 7th, 1855 when the first Russian-Japanese contract called Treaty of Shimoda was signed in Shimoda city. On April 5th, 1857 the decree of tsar Alexander II about the publication of the Treaty of Shimoda in "Senate gazette» was enacted (Grimm, 1927).

\section{Methods}

In order to perform a periodization of stages of development of trade and economic relations of Russia and Japan three criteria have been taken as a basis:

1. Criterion of qualitative change of trade and economic relations of two countries - involvement of the universal trading companies in in bilateral trade, development of coastal trade, formation of new directions of 
foreign economic relations, qualitative change of trade structure of two countries, creation of joint ventures, joint development of regions etc.

2. Criterion of diplomatic development of the relations of two countries - signing of qualitatively significant economic contracts, agreements, and declarations which imply development of already existing forms of communications, cover important problems of development of trade and economic relations, and also lay the foundation for the future development. This criterion also includes agreements on the foundation of strategically important Russian-Japanese joint associations and organizations expected to stimulate the further development of the external economic relations.

3. Criterion of political events which had a direct impact on the development of economic relations of two countries - military events, change of a political system, and also economic policy change.

\section{Results}

Stages of historical development of the Russian-Japanese trade and economic relations, as well as emergence of new forms of trade and economic relations, to a basis of which the principle of qualitative change of the Russian-Japanese trade and economic relations is put, are shown in table 1.

Table 1. Chronology of development of the Russian-Japanese trade and economic relations

\begin{tabular}{ll}
\hline Period & Name of the period \\
\hline $\begin{array}{l}\text { From the beginning of } \\
\text { XVII century to 1855 }\end{array}$ & The first pages of the Russian-Japanese relations \\
$1856-1903$ & Formation and development of the system of economic relations of Russia and Japan \\
$1904-1925$ & The military period \\
$1926-1955$ & Restoration of the Soviet-Japanese relations \\
$1956-1980$ & Growth and development of the Soviet-Japanese relations \\
$1981-2000$ & Trade and economic relations at the turn of the XIX-XX centuries \\
$2001-2013$ & The newest period of the Russian-Japanese trade and economic relations \\
\hline
\end{tabular}

So, interaction of two countries has a long history. Relations between Japanese and Russian have begun its formation in the end of XVII-XVIII centuries.

January 20th, 1925 is considered to be a starting point of the new (already) Soviet-Japanese relations. Signing of the Beijing Convention has given an impulse to legal settlement of the Soviet-Japanese relations which, in turn, stimulated active growth and development of bilateral trade of two countries. From 1925 to 1930 turnover between Russia and Japan has increased more than by 2 times, to be more precise - from 12 to 26 million rubles. Dynamics of turnover in 1925-1950 is displayed in picture 1 .

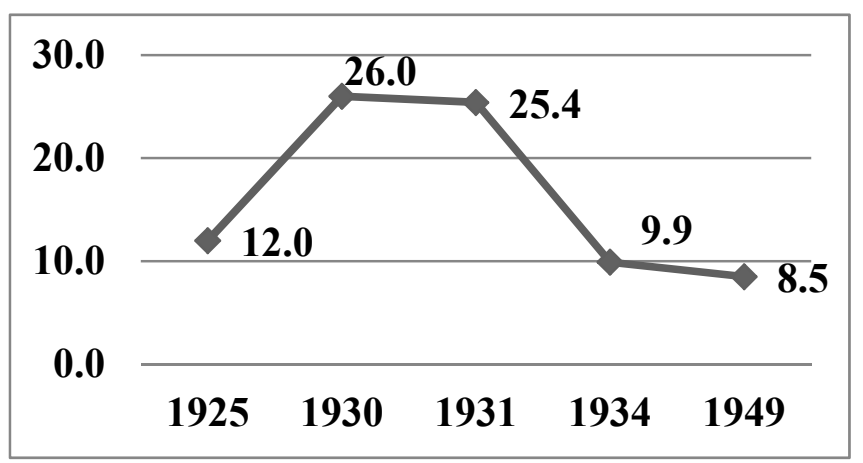

Figure 1. Turnover of Russia and Japan during the period of 1925-1950s, (in million rubles) (Statistics Bureau, 2014) 
With the start of the Great Patriotic War in Russia all negotiations between two countries were suspended, and all the trade relations were completely stopped. A 'wreath' of this period was the Soviet-Japanese war in August, 1945. Trade relations between two countries have renewed only in 1946-1949 and represented intergovernmental agreements under open account or clearing. The volume of such operations was insignificant, and trade turnover between Russia and Japan in 1949 made up 8,5 million rubles. During the post-war period the largest items of the Soviet export to Japan were the Sakhalin coal, cellulose, and a kraft paper. In turn, such goods as steam locomotives, cars, tanks, refrigerating equipment, boats, and small fishing vessels (Dolgorukov, 1978) were imported from Japan during these years. By the year 1951 the Russian-Japanese trade turnover has reached record-breaking low indicators, making up only 0,5 million rubles. Since 1952 Japan also has started the movement for the restoration of commercial relations with the USSR. During this period the Committee on the Japanese-Soviet trade assistance, transformed in 1955 into Association of the Japanese-Soviet trade, was founded. In 1954 the committee on the assistance of the Japanese-Soviet trade in the Japanese parliament was formed. An important role in the revival of the economic relations belongs to the Association on the assistance of the international trade development ("Kokubosoku").

1956-1980 year period should be highlighted as the next stage of the Russian-Japanese trade and economic relations. The main feature of this period is an active involvement of the largest corporations of Japan (the universal trading companies) into international trade between Russia and Japan. It is necessary to note that active involvement of such trading giants as "Mitsui Bussan", "Mitsubishi Corp.", "Sumitomo" and other has been conditioned by the events of 1956-1958. Right during this period (in 1956) the visit of the Prime minister of Japan I. Hatoyama to the USSR took place.

So, already by the beginning of 1975 , over 20 Japanese trading firms had 16 permanent representative offices in Moscow. In December, 1970 the Soviet-Japanese committee on economic cooperation was founded in Moscow. Foundation of this committee might be considered as a new form of the organization of the foreign trade relations. This committee triggered national projects which had a relationship with the regions of Siberia and the Far East of Russia. These projects include:

1. The construction project of Vrangel port started in 1970 (nowadays Vostochny Port).

2. The project of the South Yakut coal basin development.

3. The project of investigation and development of the gas fields in Yakutia.

4. The project of investigation and development of oil and gas deposits at continental shelf of Sakhalin during the 1970-1980 year period which triggered the Sakhalin shelf projects.

The interstate agreements signed in 1956-1958 have allowed two countries to enter a new stage of the trade and economic relations. As result, Japan has become one of the first trading partners of the USSR (Kozhevnikov, 2005), while Soviet Union has become one of the ten largest trading contractors of Japan. As it was already mentioned above, the basic contribution to the development of the bilateral trade was provided by the universal trading companies of Japan, the share of which in the total sum of the export/import contracts was over $80 \%$ (see table 2).

Table 2. Unit weight of the leading Japanese trading companies in the Japanese-Soviet trade (on the basis of the concluded trading contracts, in \%) (Statistics Bureau, 2014)

\begin{tabular}{cccc}
\hline Trading company name & $\mathbf{1 9 7 0}$ & $\mathbf{1 9 7 5}$ & $\mathbf{1 9 8 1}$ \\
\hline Turnover, total & 100 & 100 & 100 \\
"Mitsui Bussan" & 27,8 & 15,9 & - \\
"Itochu" & 12,8 & 11,5 & 13,5 \\
"Sumitomo" & - & 14,9 & 14,6 \\
"Nissho Iwai" & 10,4 & 7,7 & 11,6 \\
"Marubeni" & 10,2 & 7,5 & 10,4 \\
"Mitsubishi" & 7,4 & 11,8 & 11,2 \\
"Nichimen" & - & 8,5 & 11,7 \\
\hline
\end{tabular}


The basis of the Soviet export to Japan during this period was formed by woods, as well as oil, petrochemical products, and solid fuel (coal). It is necessary to note that that the share of the machinery and technical products in export was insignificant and made up less than $1 \%$ out of all export products. The structure of the Soviet import, on the contrary, had more diverse structure. So, its basis was formed by the industrial goods, the greatest share of which belonged to cars and equipment of the Japanese production. Another not less significant item of the import was the hire of ferrous metals and pipes.

The second qualitatively new characteristic of the 1970-1980 period was growth and development of the so-called coastal trade, the purpose of which was the involvement of the small and medium-size prefecture enterprises adjoining the sea of Japan into international trade.

Thus, the period of 1957-1980s indicates that large-scale success has been reached in the sphere of trade and economic relations between Soviet Union and Japan. The Soviet-Japanese trade gained a big scope, and its volume for hardly more than twenty years has increased by 60 times (Pond, 2012).

The period of 70-80s was characterized by the occurrence and active advancement of new and more complicated forms of economic communications (such as coastal trade), which have led to the establishment of the long-term relations of economic cooperation and have put a basis to the qualitatively new trade and economic relations of two countries.

When considering the following stage (from 1981 to 2000) it is necessary to pay attention to the period of 1989-1990. During this two-year period the trade of two countries has reached its historical maximum since 1960s (see picture 2).

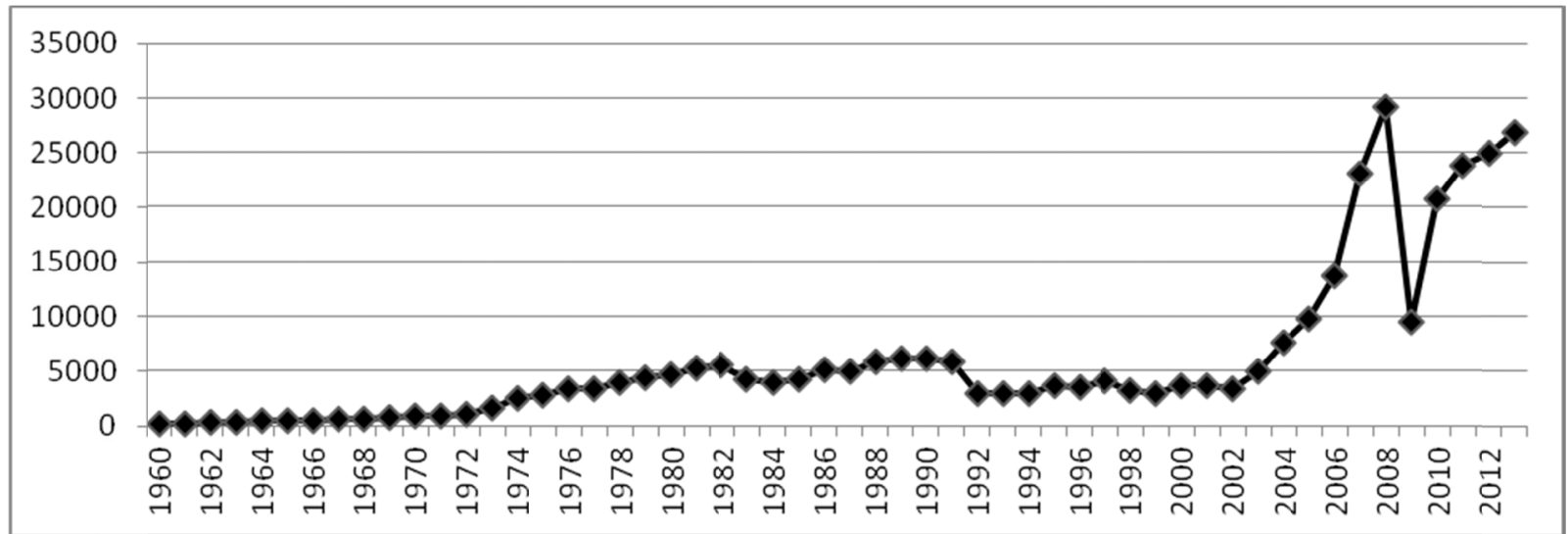

Figure 2. Turnover between Russia and Japan in 1960-2013, million dollars (Federal service of the state statistics, 2014)

After that, the pace of the Russian-Japanese communications started to slow down, as well as delays in payment of the foreign trade transactions started to take place. In 1991 dissolution of the USSR occurred, and already in 1992 foreign trade turnover made up only half of the 1989 turnover. The old nomenclature was replaced by the consumer goods, namely the Japanese home appliances and cars (second-hand, by the most part).

Modern (the newest) stage of trade and economic relations (2001-2013) is considered to be a stage when globalization started to be the leading tendency in the world. According to the picture 2, it is obvious that it is possible to consider this period as the most 'fruitful' period over the all history of the Russian-Japanese trade and economic relations.

The majority of analysts agree that the merit of such dynamical development belongs to a new course of the Russian Federation on the world economic arena (Larin, 2008). The special attention here has been given to the interaction of Russia and Japan at the regional level which is distinguished, first of all, by the community of economic interests (not the interests of the centers, but the interests of the peripheries or regions). Over the last years Japan has actively participated in world political and commercial relations, paying special attention to the communications in the Pacific Rim, as a considerable part of its economic interests (more than $80 \%$ of its foreign trade (Kangas, 2007) is integrated into this region.

The energy sphere is still a leading sphere of trade and economic relations of Russia and Japan. Here Russia and Japan perform joint Sakhalin oil and gas projects "Sakhalin-1" and "Sakhalin-2". Within the frameworks of the 
project "Sakhalin-2", the shipment of the liquefied natural gas to Japan has been started since February, 2009. Also, it was offered to the Japanese side to take part in the project "Sakhalin-3".

Activity of Russian company "Rosneft" on the creation of the joint Russian-Japanese enterprises for the development of the shelves of sea of Okhotsk, as well as geological investigation in the Eastern Siberia, and joint Russian-Japanese development of oil and gas deposits around Kuriles is remarkable.

The special attention, as it was already mentioned above, is given to atomic engineering. State corporation "Rosatom" together with Japanese companies "Mitsui" and «Marubeni» are discussing the questions of joint participation in the development of uranium deposits both on the territory of Russia and the third countries.

\section{Discussion}

Many researchers agree on the underdevelopment of the Russian economy which influences the structure of goods turnover of Russia and Japan.

P. S. Pimenov notes dynamism of the economic development of two countries over the last years, but he also pays attention to a problem of turnover structure which does not meet economic potential of the countries (Pimenov, 2011). M. V. Filippova notes that energy strategy of Japan and its interests make the Far East Russia the locomotive of perspective development of the Russian-Japanese relations in the future (Filippov, 2010).

It is important to stress that the Japanese scientists find relations between Russia and Japan as important from the geopolitical and economic point of view, as well as requiring cooperation (Sakamoto, 2013). E. Koyama names Russian-Japanese relations as mutually supplementing. Also, the author especially underlines mutual interest of two countries concerning the future development of trade and economic relations (Koyama, 2011). R. Kangas, professor of the European Centre of safety researches names the Far East of Russia as dynamically developing (Kangas, 2007). The point of view concerning the external economic strategy of Japan and the role of the Far East Russia as region-supplier of power resources in it is shared also by such western researchers as Williams Brad (Williams, 2006). However, points of cooperation of Russia and Japan still have not been found, which makes this topic problematic and promising.

\section{Conclusion}

Interaction of two countries in 2000-2013 has provided an active growth of turnover. The basic priority of interaction noted in such spheres of trade as mechanical engineering, power, woods, and chemical industry. It is obvious that trade of Russia with Japan still has a character of exchange of the Russian fuel, raw materials, and seafood on the Japanese finished industrial products. Speaking about tendencies of the Russian-Japanese trade and economic relations of the last years it is also important to note a course of mutually advantageous integration of the Russian and Japanese business on the territory of Russia, in particular on the territory of the Far East (Koyama, 2011). The parties continue to undertake more and more close cooperation in such spheres of business as power, agriculture, infrastructure, and transport. Russian market today is considered to be very appealing to the Japanese business in terms of resources, as well as the Russian business, in turn, is extremely interested in the Japanese business as a source of technologies, investments, and knowledge.

\section{References}

Dolgorukov, P. D. (1978). Trade and economic relation of the USSR with Japan, "the USSR-Japan: To the 50 anniversary of an establishment of the Soviet-Japanese diplomatic relations (1925-1975)".

Filippov M. V. (2010). The Far East Russia in power strategy of Japan (p. 144).

Grimm, E. D. (1927). Collection of contracts and other documents on history of the international relations in the Far East 1842 - 1925 (p. 218).

Kangas, R. (2007). The Changing Face of the Russian Far East: Cooperation and Resource Competition Between Japan, Korea, and China in Northeast Asia. PGDT (Perspectives on Global Development and Technology), 6, 441-460. http://dx.doi.org/10.1163/156914907X207829

Kozhevnikov, V. V. (2005). Russian-Japanese relations in XXI century: What they will be? (Subjective views of the historian). Bulletin the Russian Academy of Sciences, 4, 12-19.

Koyama, Y. (2011). Integration of the economy of the Russian Far East into the economic area of Northeast Asia. International Conference Enterprise. Niigata University: 1666-1680.

Larin, V. L. (2008). Pacific Russia in the modern policy of Japan. Bulletin of the Russian Academy of Sciences, 5, 3-16.

Lensen, G. A. (1954). 1923 - Report from Hokkaido: The Remain of Russian culture in Northern Japan. 
Hakodate (p. 216).

Masami, A. (1920). Goshkevich, Russian consul in Hakodate. Tokyo, 2, 141-146.

Pimenov P. S. (2011). Features and prospects of development of trade and economic relations between Russia and Japan. The Bulletin of the Russian State Humanitarian University, 10, 296-302.

Pond, E. (2012). Japan and Russia: The view from Tokyo. Foreign Affairs, 52(1), 141-152. http://dx.doi.org/ $10.2307 / 20038035$

Sakamoto K. (2013). About Russian-Japanese cooperation. Article in the Japanese newspaper "Yomiuri". Retrieved March 28, 2014, from http://the-japan-news.com/

Seigo, M. (1961). Hoppo torai. Jiji Tsushinsha, Showa, Tokyo, p. 224.

Statistics Bureau. Ministry of Internal Affairs and Communications. Retrieved February 10, 2014, from www.stat.go.jp/english/data/index.htm

Williams B. (2006). Federal-regional relations in Russia \& the Northern Territories dispute: The rise and demise of the "Sakhalin factor". Pacific Review, 19(3), 263-285. http://dx.doi.org/10.1080/09512740600875028

Federal service of the state statistics. Retrieved January 25, 2014, from www.gks.ru/wps/wcm/connect/rosstat main/rosstat/ru/statistics/ftrade/

\section{Copyrights}

Copyright for this article is retained by the author(s), with first publication rights granted to the journal.

This is an open-access article distributed under the terms and conditions of the Creative Commons Attribution license (http://creativecommons.org/licenses/by/3.0/). 